\title{
Evaluation of Bearing Capacity of Geogrid Reinforced Foundation
}

\author{
Yang Jun jie, Kumamoto University \\ Ochiai Hidetoshi, Kyushu University \\ Hayashi Shigenori, Kyushu University
}

\begin{abstract}
The bearing capacity of foundation ground with one layer geogrid is formulated based on the upper bound theorem of plasticity theory. The failure mechanism of reinforced foundation ground is obtained through use of results of model tests. Two reinforcing effects are considered in the proposed formula. One effect is that the failure zone is extended, which is reflected by the enlarged angles of the rigid triangular wedge under the base of footing. Another is that the shear resistance on the two lateral sides of the wedge increses. The calculated results are compared with the loading test results.
\end{abstract}

\section{概 要}

ジオグリッドを一層敷設した補強基礎地盤の支持力評価を検討する．ジオグリッド を基礎愊より浅く敷設した場合，模型載荷試験により補強基礎地盤はジオグリッド を横切って無補強の場合に比べてよりきいすべり面が発生する形で破壊する。こ のような破壤メカニズムを用い, 速度場法の理論を援用し, 補強基整地盤の支持力 を，破壊域拡大の効果とせん断抵抗の効果を考虑した評価方法を示し，実験結果と 比較した。 
ジオグリッド補強基礎地盤の支持力評価

熊本大学工学部 ○楊 俊傑

九州大学工学部 落合英俊

林重徳

\section{1.まえがき}

図-1に示すような，ジオグリッドを地盤内に一層敷設することによって支持力の増加を図る 方法は，基礎地盤の補強工法の一つである．この補強基礎地盤の支持力は，表-1に示すような 影撆要因に支配されるものである.

著者ら が作用する場合を対象として，ジオグリッドの種類，敷設深さと敷設幅，基礎幅，地盤密度が補 強基礎地盤の破壊形態，支持力特性，ジオグリッド敷設による補強の効果に与える影響およびそ れらの相互の関係を実験で調へた。また，極限釣合法による慣用の支持力公式に補強効果を組み 入れることによって補強基整地盤の支持力評価式を提案した ${ }^{2)}$ が，慣用の支持力公式における支 持力係数 $\mathrm{N}$ rは解析で表せないので，補強材敷設によって変わる補強効果の評価が複雑になり， 実用的でない。

一方，速度場法は極限解析法の一つであり，正解値との位置づけが分かること，また，合理的 な破壊メカニズムを設定できれば，実務でも比較的利用され易いことから，支持力問題，土王問 題，斜面の安定問題によく用いられている ${ }^{3)}$ 。速度場法を補強土構造物の安定解析に適用できれ ば，有力な手法になり得る。

そこで，本文は，速度場法を用いて補 強基礎地盤の支持力の評価を試みる.

2. ジオグリッド補強基礎地整の支持力

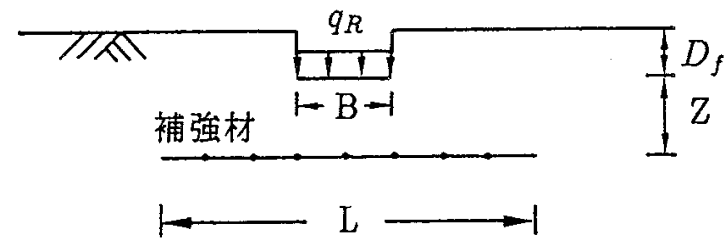

ジオグリッドを一層数設した補強基砧 地帮の表面に帯状荷重を想定した模型載 荷試験より次の結論が得られている。

(1) 補強効果が最大となる最適敷設深 さが存在する.この最適敷設深さ $Z$ 。は 地盤の密度, 補強材の敷設幅とその種類 にかかわらず，ほぼ基礎愊 $\mathrm{B}$ と同程度 ( $\left.Z_{\circ} \leadsto \mathrm{B}\right)$ である.

（2）補強材を最適敷設深さより浅く敷 設した補強基礎地篮（ $Z<Z_{0} \leftrightharpoons B ）$ は,

図-1 ジオグリッドを一層敷設した補強地盤の 概念図

表- 1 補強基礎地盤の支持力に及ぼす影㸷要因

\begin{tabular}{|c|c|}
\hline 項目 & 影響因子 \\
\hline 基礎 & 幅 $\mathrm{B}$ ，根入れ深さ $\mathrm{D}_{f}$ \\
\hline 地盤 & 粘着力 $\mathrm{c}$, 内部摩擦角 $\phi$, 単位体積重量 $\gamma$ \\
\hline 補強材 & $\begin{array}{l}\text { 敷設深さ } Z \text { ，敷設幅 } \mathrm{L} \text { ，引張り強度 } \mathrm{Fu} \\
\text { 許容伸びひずみ } \varepsilon_{0} \text {, 土との摩擦特性 } \delta\end{array}$ \\
\hline
\end{tabular}


補強材を横切る形で破壊する.この場合，敷設深さを增加すれば補強の効果も増加する．また， 敷設幅が大きいほど補強効果は大きくなるが, 敷設幅が基礎幅の 3 倍程度までは補強効果は顯著 に增加し，敷設幅が基整幅の 3 倍程度以上になると増加の程度が小さくなる。

（3）補強材を最適敷設深さより深く数設した場合（ $\left.Z>Z_{0} \fallingdotseq B\right)$, 補強基礎地政は, 補強材 の上面で破壊する。この場合，敷設深さを増加したら補強の効果は逆に隇少する，一方，敷設幅 が基礎楅の 3 倍程度までは補強効果は敷設幅とともに顕著に増加するが, 敷設幅が基礎幅の 3 倍 程度以上になると補強効果はほほ一定になる。

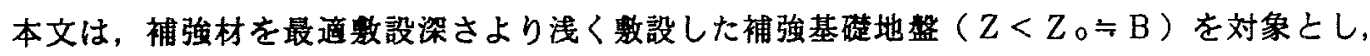
その補強効果を評価した支持力式を速度場法を用いて求めるものである.

\section{3. 速度場法による支持力評価}

速度場理論による上界值計算の結果がどれほど正解值に近いかは，ひとえに仮定された破壊メ カニズムが,いかに現実の物理現象を 忠実に表現しているかにかかっている 3)と言われている．従ってまず最初に, これまで実施した模型載荷試験の結果 に基づいて，ジオグリッドによる補強 基礎地盤の破壊のメカニズムを考察す る.

3-1.補強基礎地盤の破壊メカニズムと 可容速度場について

a）補強基礎地盤の破壊メカニズム の設定

図一2は，砂地盤（ $\phi ）$ 内に基砝幅 $\mathrm{B}$ の3〜7倍程度の愊でジオグリッドを 一層浅く敷設した場合 $(Z<B)$ に, 試験終了後の地盤の断面を撮影した写 真から求められたすべり面の形状を示 したものである.それから次の結論が 得られている.

(1)破壊形態は無補強基礎地盤のそれに 相似している.

(2)破壊域は無補強基礎地盤より大きく なる。

(3)基礎直下での破壊はジオグリッドを 横切る形で生じる.
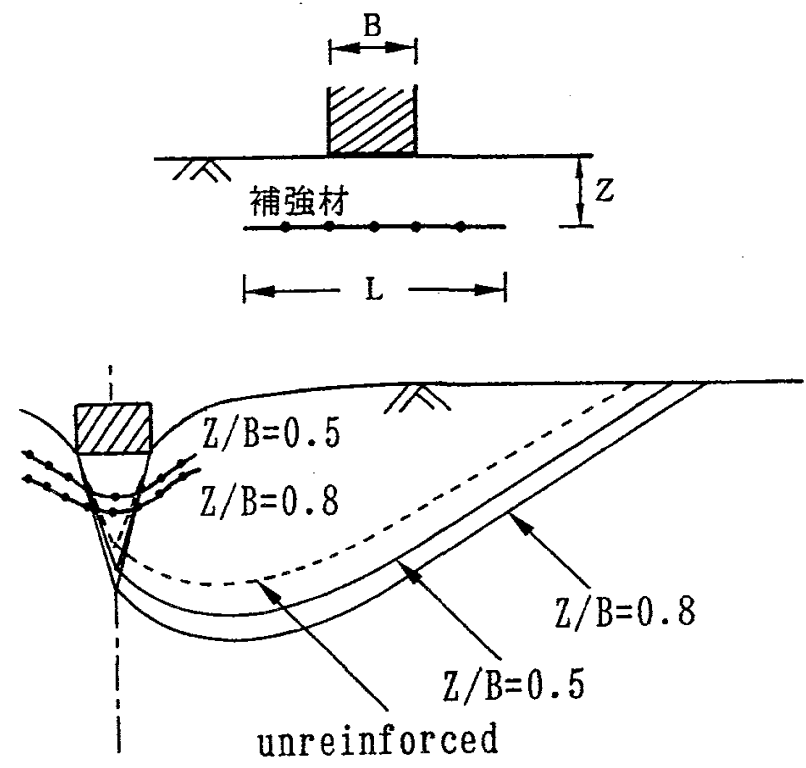

（a）敷設深さが異なる場合 $(\mathrm{L} / \mathrm{B}=3)$

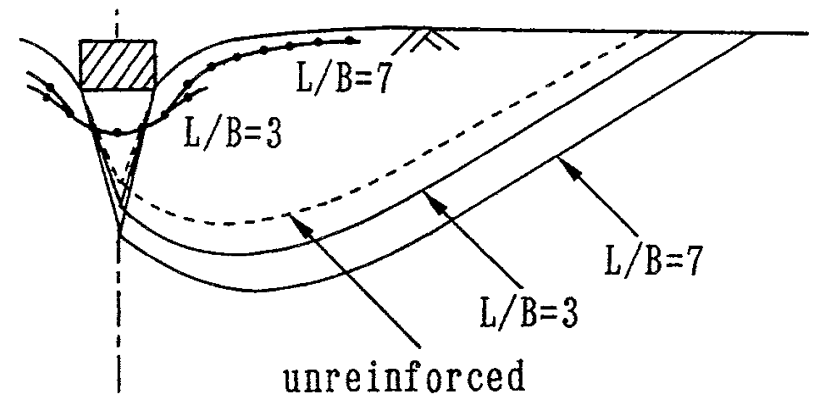

(b) 敷設幅が異なる場合 $(Z / B=0.5)$

図-2 実験終了後の地盤断面の変形状況により 求められたすべり面 
(4)基礎直下に生じる土くさび角度はジオグリッドの敷設深さおよび敷設楅とともに大きくなる. なお, 対象とする浅い基礎（ $\mathrm{D}_{\mathrm{t}} \leqq \mathrm{B}$ ) の補強基礎地盤には, 土被り王の効果を等価サーチャ 一ジ荷重（ $\gamma \mathrm{D}_{t} ）$ として考え，地表面載荷の場合と同様なすべり面が生しると考える.

速度場法を適用して支持力を求めるために，図一 2 に示すような実験で求められたすへり面を 次のように数学的に表現し直す.

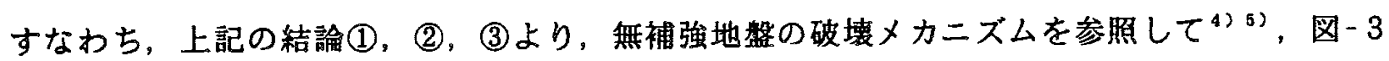
に示すような破壊メカ二ズムを設定する。cdを対数ら線に，deを直線に仮定する. cd とdeを骬ら かに接させるために角度くedd を( $\pi / 2-\phi)$ とする. deと水平線の交わる角度を $\alpha$ とし，この $\alpha$ は得られる支持力の上界値を最小とするように決められる.

図-2に示すようなジオグリッド敷設による破壊域拡大の効果を，土くさび角度 $\omega$ が敷設によ って変化するものとして評価する。すなわち, 基礎直下に無補強の場合より大きい土くさび角度

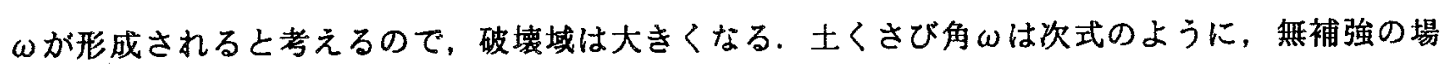
合の土くさび角 $\omega_{0}$, 補強材の伸び剖性, 引張り強度, 土との摩擦特性, 敷設㽬, 敷設深さおよ び土くさびの側面で生しる引張り力によって異なると考えられ，3-4節で検討する.

$$
\omega=\mathrm{f}\left(\omega_{0}, \varepsilon_{0}, \mathrm{~F}_{\mathrm{u}}, \delta, \mathrm{L}, Z, \mathrm{~F}_{\mathrm{Tm} \mathrm{x} x}\right)
$$

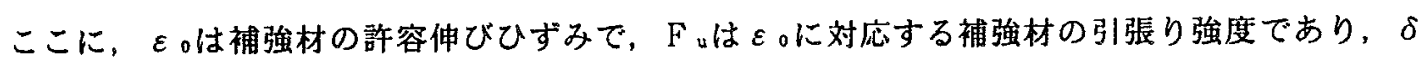
は補強材と土との摩擦特性を表すパラメータで，F T max は土くさびの側面での補強材の引張り力 である.

b）補強基礎地笽の可容速度場について

a)項で述へたように補強材敷設方法によって補強基礎地盤の破壊メカ二ズム(土くさび角度 $\omega$ ) が変わるので, その可容速度場は無補強の場合と異なり, 敷設方法によって変わる.

図-3に示すような破壊メカニズムが可容速度場となるように，図-4のようなホトグラフによ

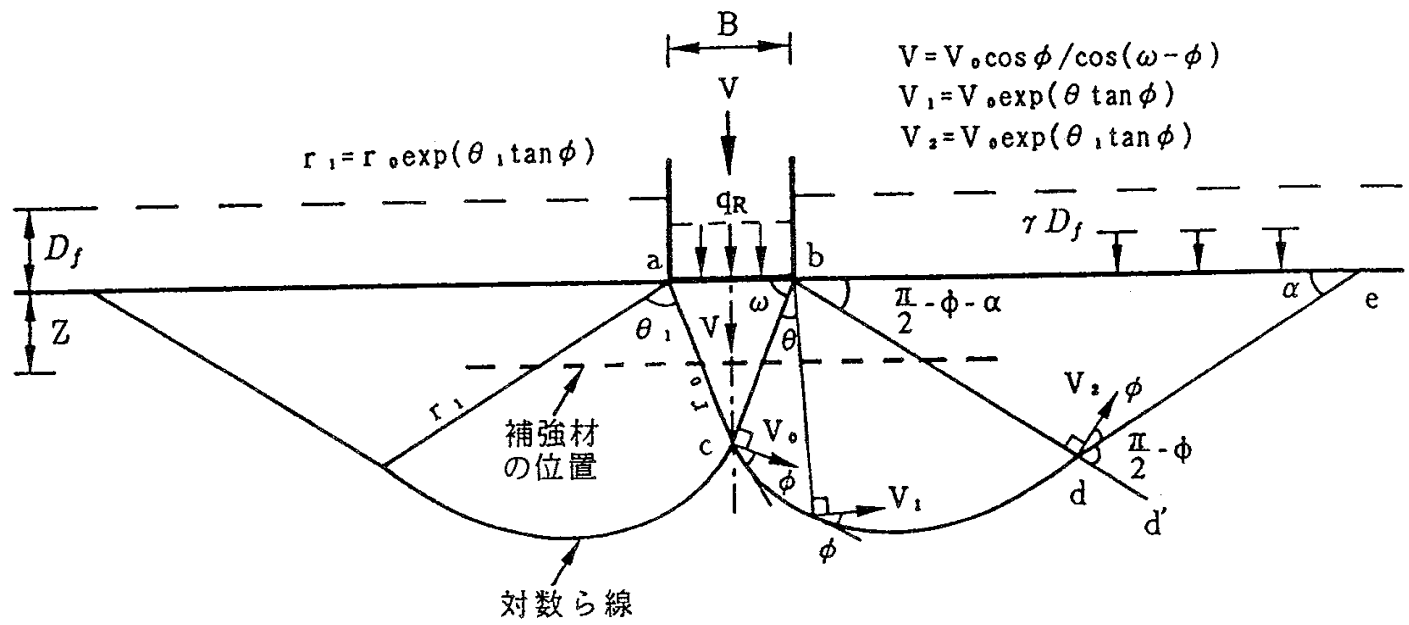

図-3 破壊メカニズムと可容速度場 
り速度成分を決定する.

土くさびが基礎と共に速度Vで下降するとする．図一 4 より，V。とVの関係およびbc面に沿う 速度の不連続値 $\triangle \mathrm{V}_{\mathrm{b}} \mathrm{c}$ を次のように求める.

$$
\begin{aligned}
& \mathrm{V}=\mathrm{V}_{\mathrm{o}} \cos \phi / \cos (\omega-\phi) \\
& \Delta \mathrm{V}_{\mathrm{b}}=\mathrm{V}_{\mathrm{o}} \sin \omega \cos \phi / \cos (\omega-\phi)
\end{aligned}
$$

また, bcdは対数ら線であるので，

$$
\begin{aligned}
& \mathrm{V}_{1}=\mathrm{V}_{0} \exp (\theta \tan \phi) \\
& \mathrm{V}_{2}=\mathrm{V}_{0} \exp \left(\theta_{1} \tan \phi\right)
\end{aligned}
$$

となる $3^{3)-5) . ~}$

これで，V， $\mathrm{V}_{0}, \mathrm{~V}_{1}$ および $\mathrm{V}_{2}$ は可容速度場を楧成す る.この可容速度場に基ついて，速度場法を実行できる が，まず，ジオグリッドがすべり面を横切った場合，そ のすへりに抵抗して発揮したせん断抵抗の効果は速度場

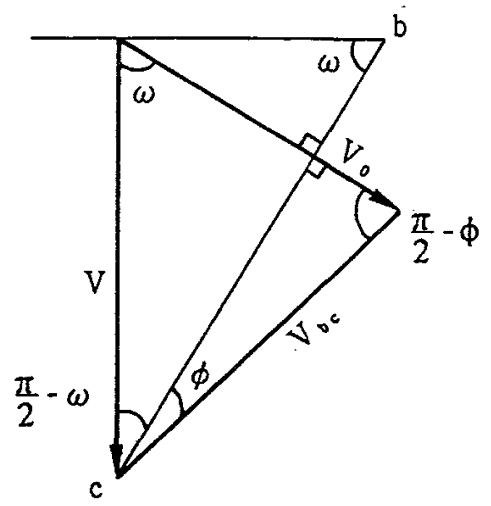

図-4 bc面に沿う速度の不連続値 法において評洒する考え方を説明する.

\section{3-2. ジオグリッドのせん断热抗の評価}

ジオグリッドが横切るすべり面 では付加的なせん断応力が生じる. この付加のせん断応力は, Jewell の方法 ${ }^{6)}{ }^{-8)}$ を利用して, 次のよう にすべり面でジオグリッドによっ て消費されるエネルギー（内部消 散）として評価する.

図一5(a)に示すように運動する 缃体は静止堋体に対してすべろう とすると, すべり面を横切る補強 材に引張り力 $\mathrm{F} \times$ が生じる.この引 張り力 $\mathrm{F}_{\mathrm{T}}$ をすべり面方向の成分 $\mathrm{F}_{\mathrm{T}} \sin \theta^{\prime}$ とすへり面に垂直な方向 の成分 $\mathrm{F} \mathrm{T} \cos \theta^{\prime}$ に分けて考えられ る.そこで, すべり面方向の成分 $\mathrm{F}_{\mathrm{T}} \sin \theta^{\prime}$ がすべりに対する直接抵 抗力になる. 一方, すべり面に垂 直な方向の成分 $\mathrm{F} T \cos \theta^{\prime}$ はすべり 面に作用する直応力を增加させる ことによって，土のせん断抵抗力

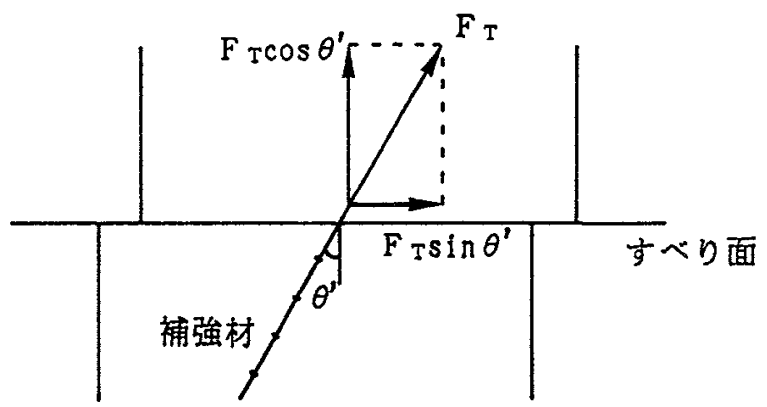

静止粑体域

（a）補強材の発揮する補強効果 運動㓮体域

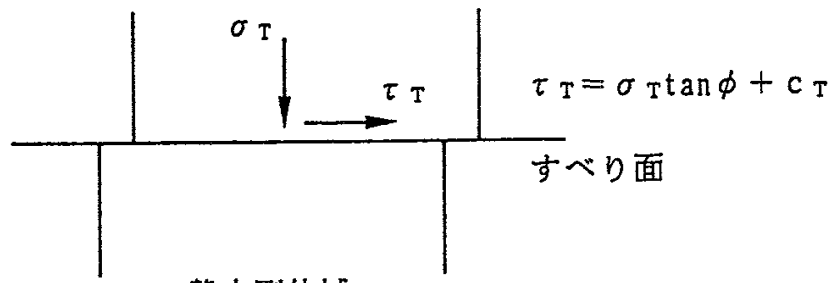

静止剛体域

(b) 補強効果の評価

図-5 すべり面と交差する補強材の効果とその評価 
が增加する.

したがって，図一5(b)に示すように，すべり面において，補強材の引張り力による，静止領域 に㗢く応力はすべり面に垂直する付加の直応力 $\sigma_{\tau}$ とすべり面に平行する付加のせん断抵抗応力

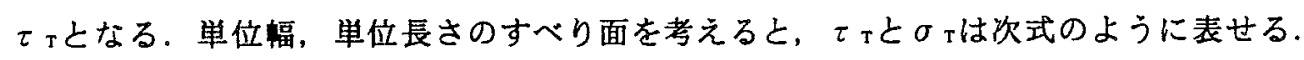

$$
\begin{aligned}
\tau_{\mathrm{T}} & =\sigma_{\mathrm{T}} \tan \phi+\mathrm{c}_{\mathrm{T}} \\
\sigma_{\mathrm{T}} & =\mathrm{F}_{\mathrm{T}} \cos \theta^{\prime} \\
\mathrm{c}_{\mathrm{T}} & =\mathrm{F}_{\mathrm{T}} \sin \theta^{\circ}
\end{aligned}
$$

ここに，Frはすべり面の位置で補強材に発生した引張力， $\theta^{\prime}$ は補強材とすべり面のなす角度で ある。

すなわち, 土自身の変形・強度特性 ( $\mathrm{cs}$ や $\phi$ 等) を向上させる化学的地盤改良工法等と違っ て, 補強土工法はせん断面に作用する直応力の増加（ $\sigma_{\tau} ）$ による土のせん断抵抗の增加（ $\sigma_{\tau}$. $\tan \phi)$ と補強材力の分力による見かけの粘着力の增加（ $\mathrm{c}_{\mathrm{T}}$ ) として評価できるものである，し たがって, 補強土搆造物において, 運動する用体プロックの速度は, 補強材を横切るすべり面と 補強材なしの土だけのすべり面において，ともに静止域に対してめだけの傾きを持つものであり， 速度場法を実行できるものと考えることができる.

補強材と交差するすべりに抵抗する補強土塊の強さによる, 静止領域に働くせん断抵抗応力 $\left(\tau_{\mathrm{R}}\right)$ は，土の本来のせん断抵抗応力 $\tau$ s 補強材によるせん断抵抗応力 $\tau_{\mathrm{T}}$ の和として考えら れ, 次式のようになる.

$$
\begin{aligned}
\tau_{\mathrm{R}} & =\tau_{\mathrm{S}}+\tau_{\mathrm{T}}=\left(\sigma_{\mathrm{S}}+\sigma_{\mathrm{T}}\right) \tan \phi+\left(\mathrm{cs}_{\mathrm{S}}+\mathrm{c}_{\mathrm{T}}\right) \\
& =\sigma_{\mathrm{R}} \tan \phi+\mathrm{c}_{\mathrm{R}}
\end{aligned}
$$

ここに， $\sigma \mathrm{s}$ と c s はそれぞれ補強材なしとした場合のすべり面上の直応力と土の粘着力である.

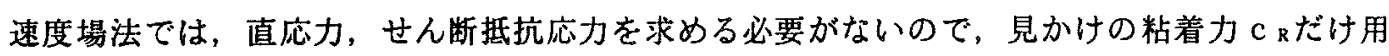
いて土だけの場合と同様な考え方にしたがい，補強材が横切るすべり面で消散するエネルギーは 次式で算定する.

$$
\begin{aligned}
E_{R} & =\left(c_{s}+c_{T}\right) \times(\text { 速度の不連続値 }) \times(\text { 速度の不連続線の長さ }) \\
& =E_{s}+E_{T}
\end{aligned}
$$

ここに， Esと $\mathrm{E}_{\mathrm{r}}$ はすべり面において，それぞれ土だけと補強材だけの消散するエネルギー（内 部消散)である.

\section{3-3.補強基礎地盤の支持力評価式}

式(9)のようにジオグリッドのせん断抵抗の効果は简単に内部消散に組み入れることができる. 以下，速度場法を用いた補強基礎地盤の支持力評価式を考える。

速度場法を補強基礎地盤の支持力問題に適用する場合，解き方等は従来の方法 ${ }^{3)}$ と同じである が，上述のようにジオグリッドと交差するすべり面でジオグリッドによる内部消散が生じる. 図 - 3 に示すように，ジオグリッドが横切るすべり面では土くさびの側面と動径すべ面が考えら れるが，ここでは，簡単のため，図-6に示すように，敷設されたジオグリッドを土くさび側面 


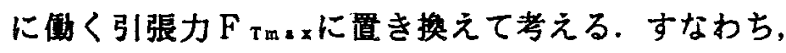
せん断抵抗の効果として土くさび側面でのジオグリッ ド数設による内部消散だけ考える.

図-6より土くさび側面に平行するジオグリッドの分 力（見かけの粘着力） c 蚮式のように求められる.

$$
c_{\mathrm{T}}=\left(\mathrm{F}_{\mathrm{Tm} \times \mathrm{x}} / \mathrm{bc}\right) \cos \omega
$$

図-3に示す可容速度場に基ついて，従来の手順に従 い, 外力仕事と内部消散を計算し, 全外力仕事と全内 部消散を等值として, 求められた補強地整の支持力は 次式に示される.

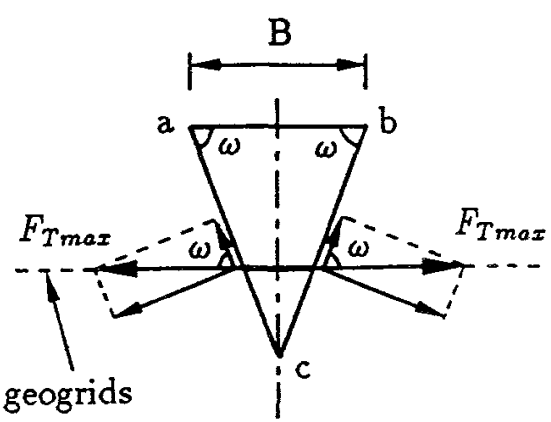

圀-6 土くさび側面に沿う 付加のせん断応力

$$
q_{R}=c N_{c}+\gamma D_{f} N_{Q}+\frac{1}{2} \gamma B N_{r}+\frac{F_{T \max }}{B} \sin 2 \omega
$$

ここに, $\mathrm{N}_{\mathrm{f}}, \mathrm{N}_{\mathrm{a}}, \mathrm{N}_{\mathrm{r}}$ は $\omega, \phi, \alpha$ の関数であり, 次式で与えられる.

$$
N_{c}=\frac{\cos (\omega-\phi)}{\cos \omega \sin \phi}\left[\frac{\sin \omega \sin \phi}{\cos (\omega-\phi)}-1+\left(\frac{\sin \phi \cos (\phi+\alpha)}{\sin \alpha}+1\right) \exp [(\pi+2 \phi+2 \alpha-2 \omega) \tan \phi]\right]
$$

$$
N_{8}=\frac{\sin (\phi+\alpha) \cos (\omega-\phi)}{\cos \omega \sin \alpha} \exp [(\pi+2 \phi+2 \alpha-2 \omega) \tan \phi]
$$

$$
\begin{aligned}
& N_{r}=\frac{\cos (\phi+\alpha) \sin (\phi+\alpha) \cos (\omega-\phi)}{2 \cos ^{2} \omega \sin \alpha} \exp \left[\left(\frac{3}{2} \pi+3 \phi+3 \alpha-3 \omega\right) \tan \phi\right] \\
& +\frac{\cos (\omega-\phi)}{2 \cos ^{2} \omega\left(1+9 \tan ^{2} \phi\right) \cos \phi}\left\{[3 \tan \phi \sin (\phi+\alpha)-\cos (\phi+\alpha)] \exp \left[\left(\frac{3 \pi}{2}+3 \phi+3 \alpha-3 \omega\right) \tan \phi\right]\right. \\
& +3 \tan \phi \cos \omega+\sin \omega\}-\frac{1}{2} \tan \omega
\end{aligned}
$$

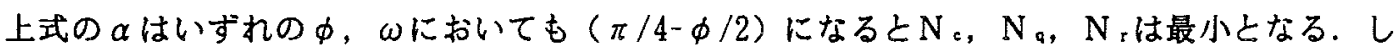

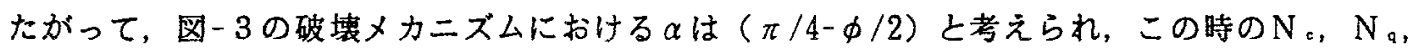
$\mathrm{N}_{\mathrm{r}}$ を補強基礎地瞥の支持力係数とする.

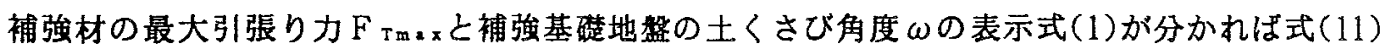
と(12)で補強基整地盤の支持力を算定できるが，本文は次のように考える. 


\section{3-4.パラメー夕 $F_{\text {Ims }}$ と}

補強の効果は補強材が装形して初 めて発揮するものであるので, 補強 の効果を考㦄するために，変位の導 入が必要になる. しかし, 速度場法 は调塑性理論に立脚するものである ため，本文は，補強土の現在の実用 設計法 ${ }^{\text {") }}$ と同じ考えを用いて極限状 態で発生されるであろう補強材の引 張り力を想定した上で速度場法を利 用する。

まず，補強材の地瞥内における状 態について考える．図一7(a)に示す ように，極限状態時，地盤内におけ る補強材は基礎端から引き抜かれる 状態にあり，引張力の分布を図一7 （b）に示すように仮定する，補強材の 最大の引張力は基礎直下で生じ，補 強材全体の伸びもそこにだけ集中し て生じるとする．ジオグリッドの最 大引張力 $F_{T m a x}$ は引抜き試験の結果 を利用すれば算定できる

$$
\begin{aligned}
F_{T_{\text {max }}} & =\tau_{\max } \cdot(\mathrm{L}-\mathrm{B}) \\
& =\sigma(\mathrm{L}-\mathrm{B}) \tan \delta
\end{aligned}
$$

ここでは簡便的に， $\sigma$ はジオグリッ ドの上面に作用する平均直応力であ

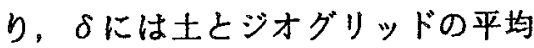
的な摩擦角を用いる。

上記の結論(4)により，土くさび角 度 $\omega$ はジオグリッドの敷設幅 (L/B) と敷設深さ $(Z / B)$ の増加と共に増加 するので，次のような土くさび角度 மの拡大の仕方を考える。

図-8に示すように，ある深さ $Z$

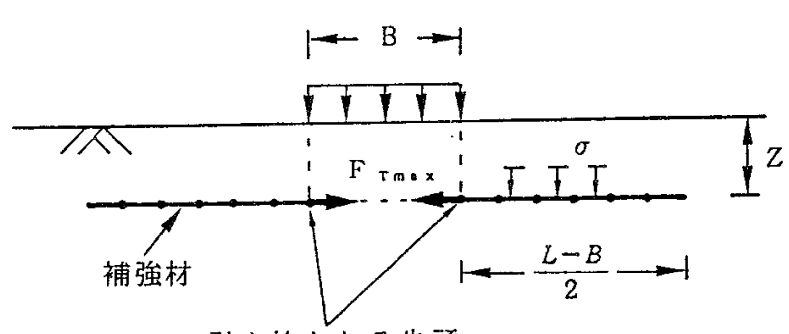

引き拔かれる先頭

（a）補強材の状態

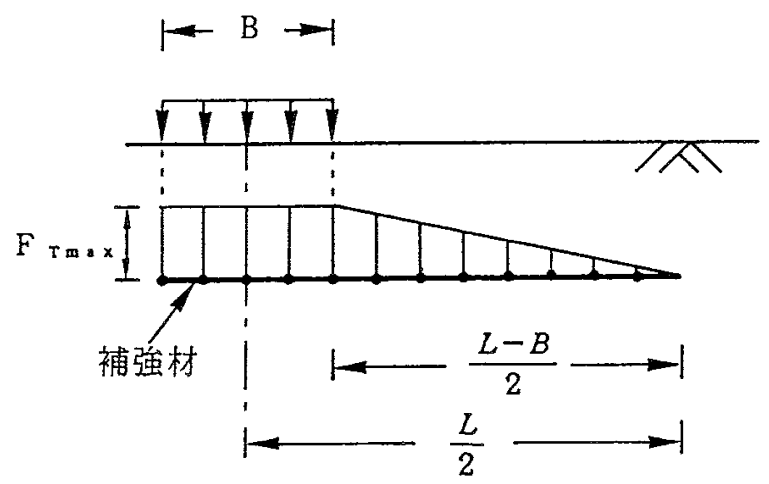

（b）補強材に生じる引張り力の分布の仮定

図-7 地盤内における補強材の状態と 生じる引張り力分布の仮定

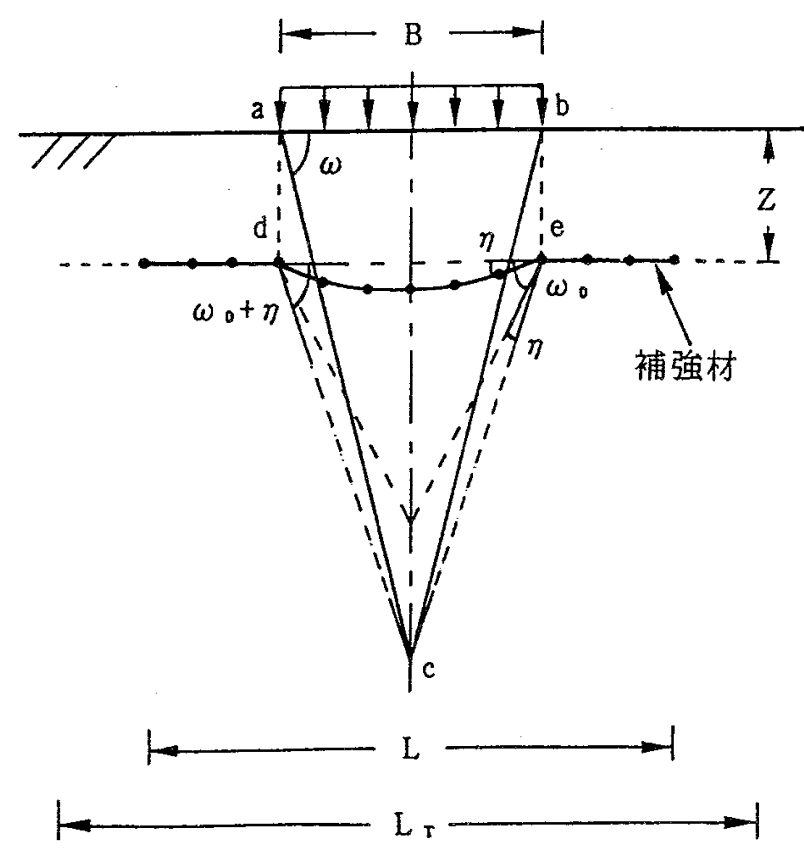

図-8 土くさび角度 $\omega$ の拡大の仕方の仮定 
（< B ）に敷設されたジオグ $1 \mathrm{~B} \rightarrow-1$

リッドの下面に無補強の場 合の土くさび角 け增加した角度 $(\omega \circ+\eta) を$ 持つ二等辺三角形を想定す る.このクはジオグリッド の伸びひずみの関数である. 図-9に示すように，ジオグ

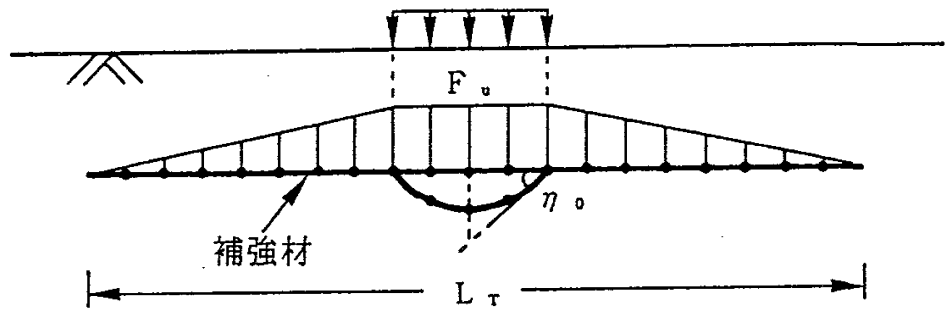

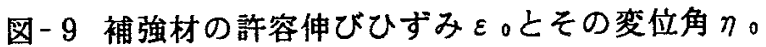

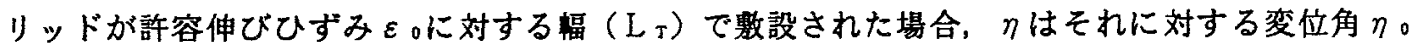
となり, ジオグリッドの引張りカ $\mathrm{F}_{\mathrm{T} m a x}$ はジオグリッドの引張り強度 $\mathrm{F}_{\mathrm{u}}$ となる．また，敷設幅

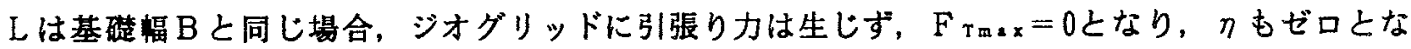
る. 基礎幅 $\mathrm{B}$ と $\mathrm{L}$ の間での数設幅 $\mathrm{L} に$ 応じた変位角クは次式で算定するすのとする.

$$
\eta=(\mathrm{L}-\mathrm{B}) /(\mathrm{L} \mathrm{T}-\mathrm{B}) \cdot \eta_{0}
$$

ここに，Lヶはジオグリッドが破断するかしないかの限界敷設猫であり，ジオグリッドの引張強 度 $F_{\mathrm{u}}$ を式(13)に代入することによって得られた(15)式で算定する．また，ク。は式(16)で算定す る.

$$
\begin{aligned}
& \mathrm{L}_{\mathrm{T}}-\mathrm{B}=\mathrm{F}_{\mathrm{u}} /(\sigma \tan \delta) \\
& \cos \eta_{0}=1 /\left(1+\varepsilon_{0}\right)
\end{aligned}
$$

式(13)と式(15)を式(14)に代入すると次式が得られる.

$$
\eta=\left(\mathrm{F}_{\mathrm{T} \mathrm{m} \times \mathrm{x}} / \mathrm{F}_{\mathrm{u}}\right) \cdot \eta_{0}
$$

次に，図-8において点aとc，bとcをそれぞれ結んで，<bac(<abc)を敷設幅と敷設深さの効 果を考虑した補強の場合の土くさび角 $\omega$ として考える. 幾何関係により $\omega$ を次式のように求める.

$$
\tan \omega=\tan \left(\omega_{\circ}+\eta\right)+2(Z / B)
$$

\section{4. 計算結果之実験結果の比較}

式(17)におけるF $\mathrm{Tmax}_{\mathrm{ma}}$ は，土被り 圧等によって異なるが，ここでは，

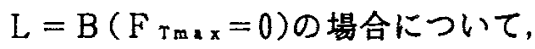
計算結果と実験結果との比較を行う。

相対密度が $83 \%(\phi=40$ 度， $\gamma=$ $1.6 \mathrm{tf} / \mathrm{m}^{3}$ とする)の砂地盤の表面に， 幅 Bが0.1mの帯状荷重を想定した模 型載荷試験を実施しだ，使用され たジオグリッドは二軸延伸SS-1であ り，その引張り強度F、的 $1.2 \mathrm{tf} / \mathrm{m} て ゙$, 許容伸びひずみ $\varepsilon$ 。は10\%である.

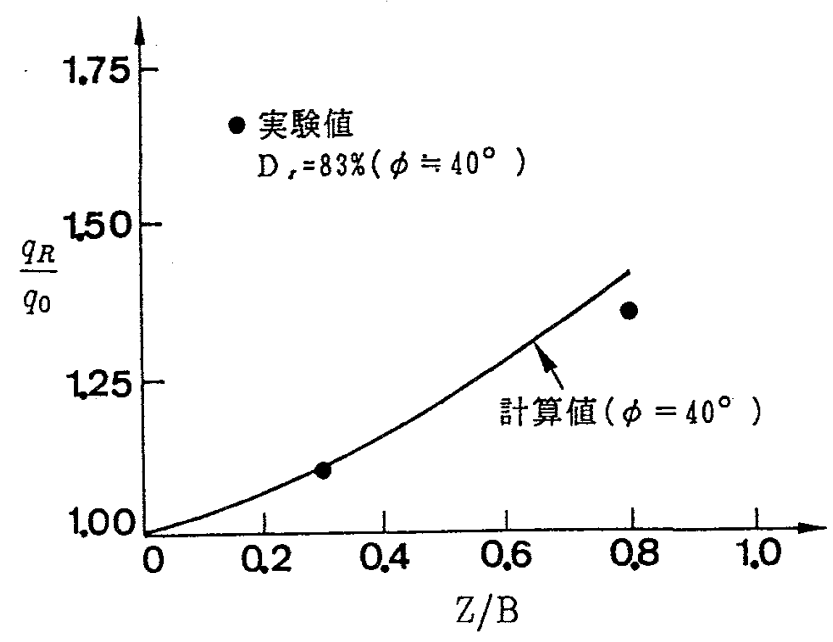

図-10 計算結果と実験結果の比較 $(L / B=1)$ 
また，土とジオグリッドの平均摩擦角 $\delta=2 \phi / 3 \leftrightharpoons 27$ 度とした. 敷設深さ $Z$ を $Z / B=0.3 ， 0.8 て ゙$ あった。これらの值を用い, 計算した支持力值と実験值を比較したものが図- 10 である.ただ し, 無補強基礎地盤の支持力 $\mathrm{q}_{0}$ は, 式(12c)において, 支持力係数 $\mathrm{N}_{\mathrm{r}}$ が最小となる時（ $\omega_{0}=$ $15+\phi$ 度）の值を式(11)の第三項に代入して算定した值を用いた. ジオグリッドを地盤内に一層 浅く敷設した場合，提案した方法により，実験結果をかなり良く評価できることが分かる.

5.あとがき

ジオグリッド補強による基礎地盤の支持力を, 破壊域拡大の効果とせん断抵抗の効果を考虑し た速度場法を用いて評洒する方法を示した．この方法による支持力の推定結果は，実験結果を比

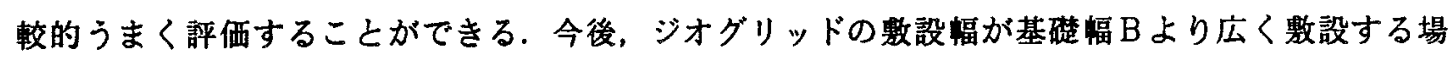
合の計算結果と実験結果を比較・考察するとともに, 補強基礎地盤の簡便かつ汎用的な支持力評 価法を検討・考察していきたいと考えている.

謝辞 : 本研究を遂行するにあたって, 九州大学工学部の大谷 順先生(現 熊本大学工学部), 梅崎健夫先生(現 信州大学工学部)には，有益な助言を，実験装置の計画作成及び実験に際して は, 同中島通夫技官に多大なご助力を賜った. また, 熊本大学工学部の鈴木敦巳先生および北 園芳人先生には仕事について便宜を図って頂き, 三井石油化学工業（株）の平井貴雄氏に補強材 に関するデータを提供して頂いた。ここに記して，感謝の意を表します.

\section{参考文献}

1）楊・落合・林：ジオグリッド補強基礎地篮の支持力特性に関する実験的研究, 土木学会論文集投稿中.

2）楊・落合：ジオグリッド補強基礎地盤の支持力式に関する一考察,

第 6 回ジオテキスタイルシンポジウム論文集, pp. 15 23, 1991. 12 .

3）木村・日下部：土の強さと地盤の破壊入門, 土質工学会, pp. 273 312, 1987.7.

4）山口: 土の力学, エンジニアリング・サイエンス講座 26 , pp. 93〜115, 1976.7.

5) Chen : Limit analysis and soil plasticity,

Developments ingeotechnical Engineering 7, 1975.

6) Jewe11, R.A. and Mroth, C.P.:Direct shear tests on reinforced sand, Geotechnique, Vol. 37, No. 1, pp. 53 68, 1987.

7）龍岡：文献抄録，補強した砂の直接せん断試験，土と基礎，Vol.36, No. 1, pp. 92 95, 1988 .

8）龍岡：ジオテキスタイルを用いた補強土工法，2．ジオテキスタイルによる補強メカニズム その 1 ，土と基礎，Vol. 41, No.3,pp.76 82, 1993.3.

9）龍岡：ジオテキスタイルを用いた補強土工法，2．ジオテキスタイルによる補強メカニズム その 3, 土と基礎, Vol.41, No. 5, pp.67〜 74, 1993.5 .

10) H. Ochiai, et al.:Pull-out behavior of polymargrid in soils and its analytical method, Hemoirs of the Faculty of Engineering, Kyushu University, Japan, Vol. 48, No. 2, pp. $125 \sim 139,1988$. 